\title{
Environmental tobacco smoke and lung function in employees who never smoked: the Scottish MONICA study
}

\author{
R Chen, H Tunstall-Pedoe, R Tavendale
}

\begin{abstract}
Objectives-To investigate the relation between lung function in employees and exposure to environmental tobacco smoke (ETS) at work and elsewhere.

Methods-Never smokers in employment (301) were identified from the fourth Scottish MONICA survey. They completed a self administered health record, which included details of exposure to ETS, and attended a survey clinic for physical and lung function measurements, and for venepuncture for estimation of serum cotinine. Differences in lung function in groups exposed to ETS were tested by analysis of variance (ANOVA), the exposure-response relation by a linear regression model, and a case-control analysis undertaken with a logistic regression model.
\end{abstract}

Results-Both men and women showed effects on forced expiratory volume in the first second $\left(F E V_{1}\right)$ and forced vital capacity (FVC) from exposure to ETS-higher exposure going with poorer lung function. This was found at work, and in total exposure estimated from ETS at work, at home, and at other places. Linear regression showed an exposure-response relation, significant for ETS at work, total exposure, and exposure time/day, but not at home or elsewhere. Compared with those not exposed to ETS at work, those who were exposed a lot had a $254 \mathrm{ml}(95 \%$ confidence interval (95\% CI) 84 to 420$)$ reduction in $\mathrm{FEV}_{1}$, and a $273 \mathrm{ml}$ (60 to 480 ) reduction in FVC after adjusting for confounders. Although lung function was not significantly associated with serum cotinine in all the data, a significant inverse relation between cotinine concentration and FVC occurred in men who had had blood collected in the morning. Casecontrol analysis also showed a significant exposure-response relation between ETS, mainly at work, and lung function. A higher exposure measured both by self report and serum cotinine went with lower lung function.

Conclusion-The exposure-response relation shows a reduction in pulmonary function of workers associated with passive smoking, mainly at work. These findings endorse current policies of strictly limiting smoking in shared areas, particularly working environments.

(Occup Environ Med 2001;58:563-568)
Keywords: passive smoking; working environments; lung function

Passive smoking is exposure of a person to environmental tobacco smoke (ETS) resulting from another person smoking. It can occur at the workplace, at home, and in public areas, where there is active smoking. Passive smoking includes both expired and sidestream smoke, and contains many of the same carcinogenic and toxic agents as mainstream smoke inhaled by active smokers. This may produce effects similar to those associated with active smoking. The adverse health effects of active smoking have been unambiguously shown in adults as well as during young adulthood, ${ }^{12}$ and passive smoking has also been shown to increase risk of cancer and cardiovascular disease. ${ }^{3}{ }^{4}$ However, the reported effects of ETS on adult pulmonary function are inconsistent or less conclusive, ${ }^{5-21}$ although passive smoking significantly reduced lung function in children. ${ }^{22-24}$ Adult pulmonary function may be affected by many other factors over a lifetime. Some previous studies failed to include potentially important epidemiological variables and to adjust for potential confounding factors, and inclusion of subjects with different backgrounds might reduce the power to detect the effects of ETS on lung function. There was also a possibility of bias in reporting smoking habits, which may have resulted in active smokers being classified as passive only. Most previous studies of exposure to ETS have dichotomised exposure into unexposed and exposed categories, which may be crude for assessment of exposure and might lead to a bias (misclassification) because such exposure may vary over time. Furthermore, there was no exposure-response relation in most of the previous studies, which could be an obstacle to assuming a causal association between exposure to ETS and reduced lung function in adults. In this study, we carried out an analysis within the fourth Scottish MONICA survey on men and women in current full time employment to investigate whether the reduction of lung function in adults was significantly associated with exposure to ETS, whether there was a significant exposure-response relation, and where the exposure was occurring.

Subjects and methods

Subjects were derived from the fourth Scottish MONICA survey in 1995, which followed a similar procedure to the Scottish Heart Health 
Study. ${ }^{25}$ Adults aged 25-64 years were randomly selected from general practitioner lists in north Glasgow, Scotland. The sample was stratified by sex and 10 year age bands to obtain similar numbers of participants of each age. In total, 1836 subjects (865 men, 971 women) participated in the fourth Scottish MONICA survey, with a $65.8 \%$ response rate. They completed a self administered personal health record and a food frequency questionnaire. Details of active and passive smoking were recorded. Current smokers were defined as those who responded to the question, "Do you smoke cigarettes now?"-Yes, regularly or occasionally. Former smokers were those who responded negatively to this question but positively to the question "Did you ever smoke cigarettes?" Never smokers gave negative answers to both of these questions and smoked neither a cigar nor a pipe. To ascertain passive smoking, the subjects were asked "Are you regularly exposed to tobacco smoke from other people?" Responses gave four choices: yes, a lot; yes, some; yes, a little; or no, none at all. Three sources of exposure of ETS were given; workplace, home, and other places. A question for time of exposure to ETS was added: "On average, for how many hours a day are you exposed to other people's tobacco smoke?" Completeness was checked by a survey nurse.

Height and weight of the subjects were measured by standard techniques: height without shoes by portable stadiometer (Holtain, Crymych, United Kingdom) to the nearest 0.5 $\mathrm{cm}$; weight without outer heavy clothing by digital scales (Seca, Germany) to the nearest $100 \mathrm{~g}$. The forced expiratory volume in the first second $\left(\mathrm{FEV}_{1}\right)$ and forced vital capacity (FVC) were measured with a Microblab 3300 electronic spirometer (Micro Medical, England). Standardised field measurement procedures were used with subjects seated, without the use of nose clips. The study nurse demonstrated the technique, emphasising the tight fit between lips and tube and providing encouragement to breathe out as long and hard as possible to each subject. After one trial run, the best of three technically satisfactory manoeuvres was recorded by the machine. A blood sample was taken for cotinine (a metabolite of nicotine $^{25}{ }^{26}$ ) and other analyses. Socioeconomic deprivation was estimated by Carstairs scores based on census data on male unemployment, overcrowding, car ownership, and proportion of social classes IV and V in their postcode sector of residence. ${ }^{27}$

Based on the personal health record 602 subjects were identified as never smokers, and of them 301 (153 men, 148 women) who were currently in full time employment were selected for analysis. The reasons for such selection were that these subjects could provide full information on ETS including exposure at work, and would have less variation in other factors affecting lung function, being fit enough to work. Data were analysed with the SPSS statistical package (Windows version 9.0). Based on the questionnaire, the degrees of exposure to ETS were scored as: none at all $=1$, a little $=2$, some $=3$, and a lot $=4$. Exposures to
ETS at work, at home, and at other places were analysed separately, and then altogether. The total was obtained by adding up the three exposures; at work, at home, and at other places-the minimum score was 3 for nonexposure and the maximum was 12 . Subjects with scores of 3 or 4 were defined as lowest, scores of 5-6 as a little, 7-8 scores as some, and 9-12 scores as highest exposure. Difference in lung function (crude and residuals, which were obtained from measured lung function minus lung function predicted from their age and height) between groups exposed to ETS were tested with ANOVA for men and women. Exposure-response relations were examined with a linear regression model for data on the groups exposed to ETS, exposure time/day, and serum cotinine concentrations. With a logistic regression model, a case-control analysis of those with residuals less than 0 versus those greater than 0 was carried out to further explore effects of exposure to ETS on lung function. Regression models were adjusted for (1) sex, age, and height where necessary, and further for (2) deprivation score and total energy intake, and finally adding for (3) respiratory symptoms including cough and phlegm to reduce possible confounding effects.

\section{Results}

Of 301 subjects, 150 men and 147 women had their lung function measured. Among them, one man and one woman had serum cotinine concentrations $\geqslant 17.50 \mathrm{ng} / \mathrm{ml}$ (their values were 27.76 and $416.84 \mathrm{ng} / \mathrm{ml}$ respectively) and were excluded from the analysis due to possible deception about smoking in their questionnaire responses. ${ }^{26}$ Table 1 showed that there were differences in lung function among groups exposed to ETS for both men and women. These with some or a lot of exposure had a lower $\mathrm{FEV}_{1}$ and FVC than those with none or little exposure, although ANOVA showed that they did not reach the conventional significance level of $p<0.05$, perhaps because of the few subjects at the highest level of exposure. Men with higher exposure at work were younger and taller, whereas the reverse was found in women (table 1).

Figures 1 and 2 show the residuals of lung function with exposure to ETS. The predicted lung functions were:

in men

$\mathrm{FEV}_{1}=4.413 \times$ height $-0.01374 \times$ age -3.355 , $\mathrm{FVC}=5.667 \times$ height $-0.008639 \times$ age -5.209 ;

in women

$\mathrm{FEV}_{1}=3.142 \times$ height $-0.02531 \times$ age -1.328 , $\mathrm{FVC}=4.031 \times$ height $-0.02547 \times$ age -2.402 .

For men there was a significant difference in both $\mathrm{FEV}_{1}$ and FVC between exposure to ETS at work, and possibly the total exposure to ETS (fig 1), and for women results were similar but not significant (fig 2 ).

Linear regression of the combined data for men and women showed that self reported exposure to ETS was negatively related to lung 
Table 1 Age, height, and lung function in never smoking employees with different exposures to environmental tobacco smoke

\begin{tabular}{|c|c|c|c|c|c|c|c|c|c|}
\hline \multirow[b]{2}{*}{ Exposure } & \multirow[b]{2}{*}{$n$} & \multicolumn{2}{|l|}{ Age } & \multicolumn{2}{|l|}{ Height } & \multicolumn{2}{|l|}{$F E V_{1}$} & \multicolumn{2}{|l|}{$F V C$} \\
\hline & & Mean & $S E$ & Mean & $S E$ & Mean & $S E$ & Mean & $S E$ \\
\hline \multicolumn{10}{|l|}{ For men } \\
\hline \multicolumn{10}{|l|}{ At work } \\
\hline None & 55 & 39.8 & 1.4 & 1.75 & 0.01 & 3.88 & 0.09 & 4.50 & 0.11 \\
\hline Little & 51 & 40.4 & 1.4 & 1.74 & 0.01 & 3.80 & 0.09 & 4.24 & 0.11 \\
\hline Some & 32 & 40.0 & 1.9 & 1.74 & 0.01 & 3.73 & 0.10 & 4.30 & 0.12 \\
\hline A lot & 11 & 37.3 & 1.8 & 1.78 & 0.02 & 3.59 & 0.19 & 4.07 & 0.27 \\
\hline \multicolumn{10}{|l|}{ At home } \\
\hline None & 104 & 39.9 & 0.9 & 1.75 & 0.01 & 3.83 & 0.06 & 4.42 & 0.08 \\
\hline Little & 19 & 37.9 & 2.5 & 1.74 & 0.02 & 3.82 & 0.12 & 4.30 & 0.17 \\
\hline Some & 15 & 40.1 & 2.7 & 1.72 & 0.02 & 3.81 & 0.20 & 4.13 & 0.19 \\
\hline A lot & 11 & 41.8 & 3.4 & 1.72 & 0.02 & 3.47 & 0.18 & 3.86 & 0.20 \\
\hline \multicolumn{10}{|c|}{ At other places } \\
\hline None & 15 & 43.7 & 2.8 & 1.75 & 0.02 & 3.83 & 0.13 & 4.44 & 0.14 \\
\hline Little & 73 & 40.3 & 1.2 & 1.75 & 0.01 & 3.81 & 0.08 & 4.37 & 0.10 \\
\hline Some & 50 & 38.7 & 1.3 & 1.75 & 0.01 & 3.88 & 0.09 & 4.38 & 0.11 \\
\hline A lot & 11 & 37.0 & 2.9 & 1.70 & 0.03 & 3.33 & 0.22 & 3.77 & 0.26 \\
\hline \multicolumn{10}{|c|}{ Total environmental tobacco smoke } \\
\hline None & 30 & 41.6 & 1.8 & 1.76 & 0.01 & 3.94 & 0.13 & 4.61 & 0.14 \\
\hline Little & 73 & 39.6 & 1.2 & 1.75 & 0.01 & 3.82 & 0.07 & 4.35 & 0.10 \\
\hline Some & 29 & 38.9 & 1.8 & 1.74 & 0.02 & 3.71 & 0.12 & 4.19 & 0.13 \\
\hline A lot & 17 & 39.5 & 2.2 & 1.73 & 0.02 & 3.62 & 0.16 & 4.01 & 0.19 \\
\hline \multicolumn{10}{|l|}{ For women } \\
\hline \multicolumn{10}{|l|}{ At work } \\
\hline None & 62 & 38.8 & 1.3 & 1.63 & 0.01 & 2.87 & 0.07 & 3.26 & 0.08 \\
\hline Little & 54 & 38.9 & 1.5 & 1.61 & 0.01 & 2.72 & 0.07 & 3.04 & 0.09 \\
\hline Some & 15 & 38.1 & 2.1 & 1.58 & 0.01 & 2.63 & 0.12 & 2.93 & 0.14 \\
\hline A lot & 15 & 42.0 & 2.9 & ${ }_{\star}^{1.62}$ & 0.02 & 2.58 & 0.09 & 3.00 & 0.14 \\
\hline \multicolumn{10}{|l|}{ At home } \\
\hline None & 105 & 38.8 & 1.0 & 1.62 & 0.01 & 2.77 & 0.05 & 3.12 & 0.06 \\
\hline Little & 24 & 39.4 & 1.8 & 1.59 & 0.02 & 2.67 & 0.09 & 3.01 & 0.12 \\
\hline Some & 10 & 35.6 & 3.1 & 1.67 & 0.02 & 3.07 & 0.21 & 3.54 & 0.26 \\
\hline A lot & 7 & 48.2 & 4.7 & 1.63 & 0.02 & 2.52 & 0.15 & 2.81 & 0.18 \\
\hline \multicolumn{10}{|c|}{ At other places } \\
\hline None & 21 & 42.2 & 2.5 & 1.63 & 0.02 & 2.70 & 0.11 & 3.06 & 0.14 \\
\hline Little & 70 & 37.1 & 1.1 & 1.62 & 0.01 & 2.86 & 0.07 & 3.23 & 0.08 \\
\hline Some & 46 & 40.3 & 1.6 & 1.60 & 0.01 & 2.66 & 0.07 & 3.01 & 0.08 \\
\hline A lot & 9 & 41.9 & 3.9 & 1.62 & 0.02 & 2.64 & 0.13 & 2.91 & 0.17 \\
\hline \multicolumn{10}{|c|}{ Total environmental tobacco smoke } \\
\hline None & 37 & 39.5 & 1.5 & 1.63 & 0.01 & 2.88 & 0.09 & 3.22 & 0.09 \\
\hline Little & 74 & 38.3 & 1.3 & 1.61 & 0.01 & 2.74 & 0.06 & 3.11 & 0.08 \\
\hline Some & 26 & 38.3 & 1.8 & 1.61 & 0.02 & 2.73 & 0.09 & 3.15 & 0.12 \\
\hline A lot & 9 & 46.2 & 3.3 & 1.62 & 0.02 & 2.50 & 0.13 & 2.72 & 0.12 \\
\hline
\end{tabular}

${ }^{\star} \mathrm{p} \leqslant 0.05$, ANOVA
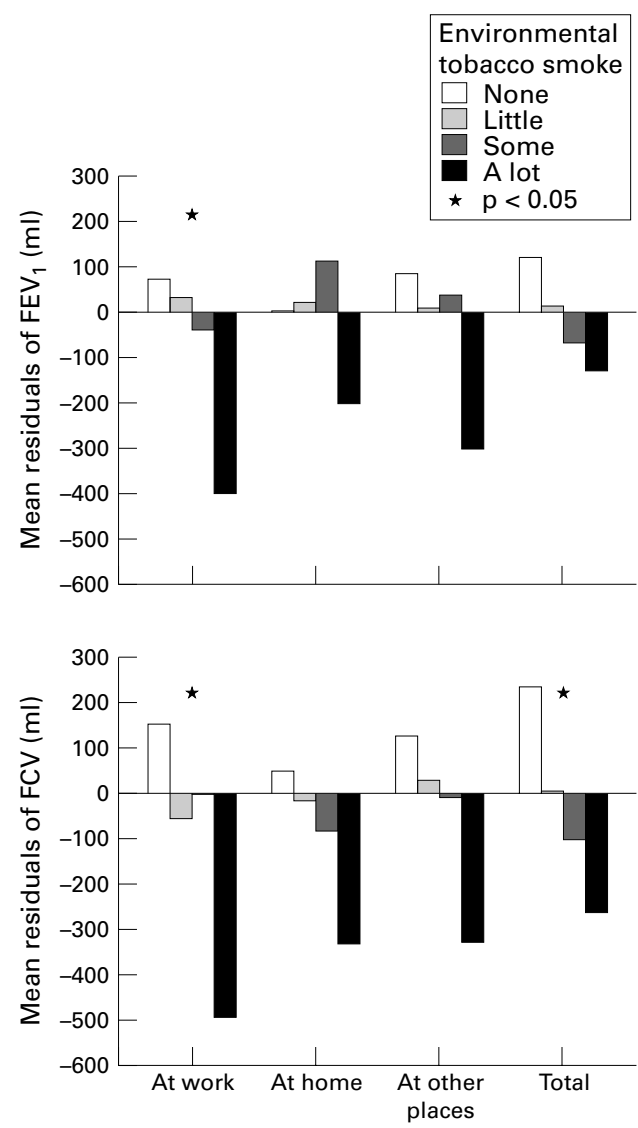

Environmental tobacco smoke

Figure 1 Mean residuals of FEV $V_{1}$ and $F V C$ by exposure to tobacco smoke for men.

(table 3), but the increased ORs were not significant for exposure at home and at other places. In the combination of self reported exposure and serum cotinine concentrations (table 4), there was a significant difference in residuals of both $\mathrm{FEV}_{1}$ and $\mathrm{FVC}$ among groups exposed to ETS (ANOVA, both $\mathrm{p}<0.05$ ), and the ORs of reduced lung function significantly increased with exposure.

\section{Discussion}

The data from the fourth Scottish MONICA survey are well suited to assess the association between ETS and pulmonary function because the data are highly standardised. These include extensive information on passive smoking from three sources, at four levels of exposure and times of day, plus serum cotinine measurements. With serum cotinine concentration $\geqslant 17.50 \mathrm{ng} / \mathrm{ml}$ as a cut off point, we were able to exclude two false non-smokers. The selection of the full time employees for analysis made the study more homogeneous. With socioecomonic deprivation (scores) as one adjustment, it was possible to rule out other confounding effects on reduction of lung function-for example, from living conditions and nutritent intake ${ }^{28-30}$ — and a further adjustment for the respiratory symptoms might reduce possible biases of overestimation or underestimation of exposure from people with symptoms. All these adjusted analyses have shown consistent results and suggest that reduced lung function in cantly increased with self reported exposure to ETS at work and possibly with total exposure 

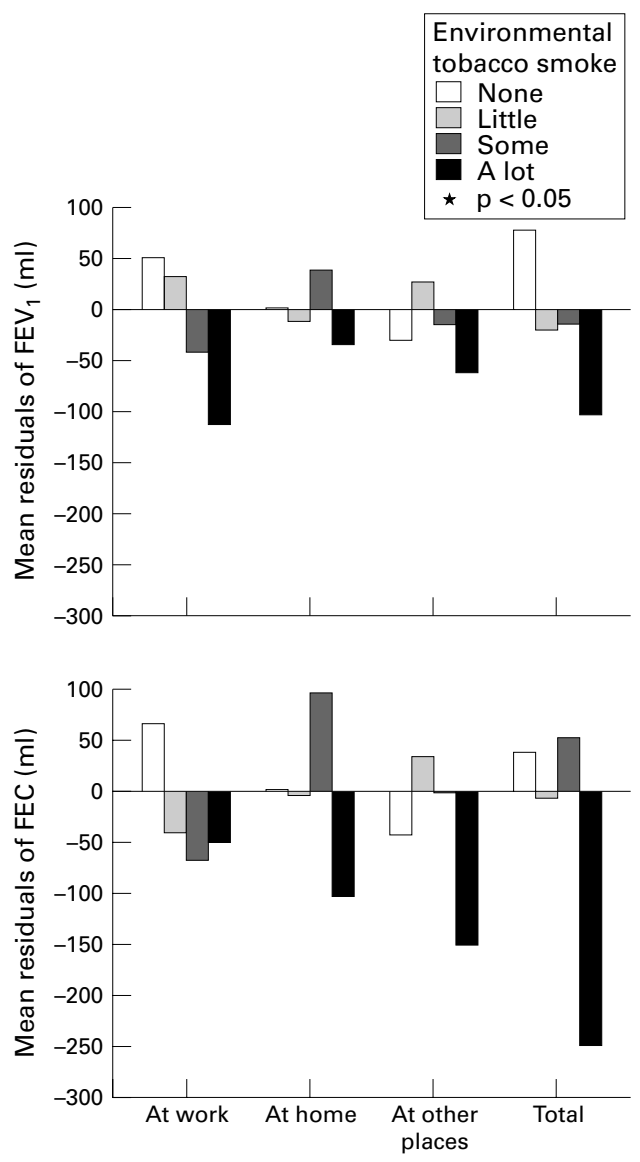

Environmental tobacco smoke

Figure 2 Mean residuals of $F E V_{1}$ and FVC by exposure to tobacco smoke for women.

employees was significantly associated with passive smoking; the effect was dose dependent and mainly from exposure to ETS at work.

Passive smoking has been significantly associated with some diseases. ${ }^{34}$ The evidence of an association between exposure to parental smoking and ventilatory impairment is relatively strong in children, ${ }^{22-24}$ but the findings of studies on the effects of exposure to ETS on lung function in adults are inconsistent. The disparate results of the previous studies could be explained by some other factors. Kauffmann et $a l^{20}$ compared 3855 French women with 2200 American women in a study of the effects of passive smoking at home on lung function, applying similar methods of analysis in women from the French air pollution study and the United States six cities study. They found that there were adverse effects in French women older than 40 years of age, although no significant effect was found among the American women. This might be from differences in lifestyle and in housing conditions between Europe and North America, leading to differences in the actual levels of exposure to ETS. It is possible that the studies indicating a non-significant relation between exposure to ETS and lung function have involved lower exposures than experienced by our study population in which we measured four levels of exposure. In some studies with negative findings, most being from America, ventilation of the buildings may be much greater because of climate so that passive exposure to smoke is actually low. ${ }^{20}$ Within Europe, housing conditions in Britain would be expected to be more equivalent to those in France, and therefore it is not surprising for us to find a reduction of lung function associated with exposure to ETS.

Svendsen et $a l^{\beta}$ noted that men with wives who smoked had lower pulmonary function than those with wives who did not smoke $\left(\mathrm{FEV}_{1} 3.491\right.$ v $\left.3.59 \mathrm{l}, \mathrm{p}=0.04\right)$. They found no dose-response relation: for measurement at baseline, $\mathrm{FEV}_{1}$ was 3.551 in men with wives who smoked $\geqslant 20$ cigarettes/day, 3.41 1 at 1-19 cigarettes/day, and 3.591 with non-smokers. Results averaged over several visits were: 3.49 1, 3.261 , and 3.491 respectively. However, in this study we identified a significant exposureresponse relation between self reported exposure to smoke and lung function among employees. If ETS is of causal importance in reduction of pulmonary function, the reduction of lung function should relate to the degree of exposure-that is, an exposureresponse relation should exist. Our results are consistent with those in other studies, ${ }^{6}{ }^{13}$ which report an exposure-response relation, and adds information on the exposure-response relation between passive smoking and reduction in lung function in adults.

When all data were analysed we did not find a significant relation between serum cotinine concentration and lung function. It might be explained by the following factors. Firstly, there could be an effect from missing data. In two men and 15 (over 10\%) women serum cotinine measurements were not available, probably introducing a bias. We found a significant inverse association between cotinine concentration and lung function in men who had blood collected in the morning, whereas there was no such relation for women. A lower rate of missing cotinine data in men than women may partly explain this. Secondly, we considered that the cotinine was an indicator of recent exposure over 1-2 previous days due to a short half life and could be largely affected by the time since last exposure to passive smoking in view of its low concentrations. Benowitz ${ }^{31}$ suggests that cotinine concentrations resulting from exposure to ETS increase slowly, reaching a peak 4-6 hours after exposure. This assumes a steady state of exposure - this may be the case for the workplace and the home but exposure in our category, other places, may vary a lot. If the total exposure to ETS is variable, the time delay between exposure and blood sampling will have an effect. In the data of the Scottish Heart Health Study, ${ }^{26}$ we did not find a good correlation between self reported degree of exposure to ETS and cotinine concentration, and suggested that validity of different measures of exposure to tobacco smoke needed further investigation. We have carried out an analysis of data from all four Scottish MONICA surveys for the non-smokers in full time employment (data prepared for publication). The results showed that cotinine concentrations were more closely related to the self reported exposure to ETS within a defined 
Table 2 Linear regression of exposure to environmental tobacco smoke and lung function in never smoking employees

\begin{tabular}{|c|c|c|c|c|c|}
\hline \multirow[b]{2}{*}{ Variable } & \multirow[b]{2}{*}{ Adjustment* } & \multicolumn{2}{|l|}{$F E V_{1}$} & \multicolumn{2}{|l|}{$F V C$} \\
\hline & & $\beta$ & $p$ Value & $\beta$ & $p$ Value \\
\hline \multicolumn{6}{|c|}{ Environmental tobacco smoke at work (score $1-4) \dagger$} \\
\hline & 1 & -0.078 & 0.004 & -0.096 & 0.006 \\
\hline & 2 & -0.085 & 0.003 & -0.092 & 0.010 \\
\hline & 3 & -0.084 & 0.003 & -0.091 & 0.012 \\
\hline \multicolumn{6}{|c|}{ Environmental tobacco smoke at home (score $1-4) \dagger$} \\
\hline & 1 & -0.022 & 0.466 & -0.072 & 0.056 \\
\hline & 2 & -0.025 & 0.409 & -0.069 & 0.072 \\
\hline & 3 & -0.023 & 0.435 & -0.067 & 0.079 \\
\hline \multicolumn{6}{|c|}{ Environmental tobacco smoke at other places (score $1-4) \dagger$} \\
\hline & 1 & -0.047 & 0.170 & -0.071 & 0.100 \\
\hline & 2 & -0.047 & 0.178 & -0.061 & 0.168 \\
\hline & 3 & -0.045 & 0.191 & -0.059 & 0.181 \\
\hline \multicolumn{6}{|c|}{ Total environmental tobacco smoke (score 3-12) † } \\
\hline & 1 & -0.037 & 0.012 & -0.060 & 0.002 \\
\hline & 2 & -0.041 & 0.007 & -0.058 & 0.003 \\
\hline & 3 & -0.041 & 0.009 & -0.057 & 0.004 \\
\hline \multicolumn{6}{|c|}{ Environmental tobacco smoke time/day $(\mathrm{h})$} \\
\hline & 1 & -0.027 & 0.006 & -0.029 & 0.018 \\
\hline & 2 & -0.031 & 0.002 & -0.028 & 0.028 \\
\hline & 3 & -0.031 & 0.003 & -0.028 & 0.032 \\
\hline \multicolumn{6}{|c|}{ Serum cotinine $(\mathrm{ng} / \mathrm{ml})$} \\
\hline & 1 & 0.009 & 0.669 & 0.002 & 0.924 \\
\hline & 2 & 0.009 & 0.647 & 0.003 & 0.816 \\
\hline & 3 & 0.011 & 0.592 & 0.008 & 0.757 \\
\hline
\end{tabular}

*Adjusted for (1) sex, age, and height; for (2) sex, age, height, deprivation score, and total energy intake; and for (3) sex, age, height, deprivation score, total energy intake, and respiratory symptoms.

†Range of scores of exposure. we would suggest that both self reported exposure and serum cotinine are used to estimate the exposure. Such a combined measurement may be a better indicator of exposure to ETS.

Carey et $a l^{14}$ reported that salivary cotinine predicted a reduction of lung function more than the self reported exposure. However, their estimation of exposure was dichotomised data, and only from exposure at the home. The authors explained that the finding may reflect the importance of exposure outside the home. Masjedi et $a l^{12}$ also found that men exposed to ETS only at home had smaller (and nonsignificant) reductions in lung function than those exposed in the workplace. Our finding showed that among three sources of ETS, only exposure at work was significantly associated with reduced lung function. Compared with ETS at work, the total exposure to ETS showed a less clear exposure-response relation between ETS and reduced lung function (fig 1, fig 2, and table 3). This could be partly explained from the combining of data from the three sources of ETS, where the durations of exposure from each source were different.

The effects of ETS on pulmonary function in adults, if any exists, are more subtle than those of active smoking because the toxic agents in passive smoking are dilute compared with mainstream smoke in active smoking. For example, particulates are about 10 times lower in sidestream smoke than in mainstream smoke. ${ }^{33} \mathrm{~A}$ recent meta-analysis showed a $2.7 \%$ deficit in adult lung function resulting from exposure to ETS. ${ }^{14}$ Our data showed a greater effect of passive smoking than other studies. ${ }^{6}{ }^{13}$ There are several possible reasons for this: (a) time limit. Thus we considered that an effect from delay between exposure and the time of blood sampling could not be ruled out. Cotinine concentrations may not be a perfect gold standard in validating questionnaires on long term exposure to ETS. ${ }^{32}$ In view of this,

Table 3 Odds ratios of exposures to environmental tobacco smoke for subjects with low versus high lung function

\begin{tabular}{|c|c|c|c|c|c|c|c|c|}
\hline \multirow[b]{2}{*}{ Exposure } & \multicolumn{4}{|l|}{$F E V_{1}$} & \multicolumn{4}{|l|}{$F V C$} \\
\hline & $O R^{\star}$ & $95 \% C I$ & ORt & $95 \% C I$ & $O R^{\star}$ & $95 \% C I$ & ORt & $95 \% C I$ \\
\hline \multicolumn{9}{|l|}{ At work: } \\
\hline None & 1.00 & & 1.00 & & 1.00 & & 1.00 & \\
\hline Little & 1.24 & 0.73 to 2.12 & 1.25 & 0.73 to 2.12 & 1.18 & 0.69 to 2.03 & 1.16 & 0.67 to 1.99 \\
\hline Some & 1.87 & 0.92 to 3.80 & 1.89 & 0.93 to 3.85 & 1.91 & 0.94 to 3.90 & 1.85 & 0.90 to 3.79 \\
\hline A lot & 3.09 & 1.23 to 7.79 & 3.12 & 1.23 to 7.87 & 2.53 & 1.02 to 6.25 & 2.47 & 1.00 to 6.12 \\
\hline \multicolumn{9}{|c|}{ Total environmental tobacco smoke: } \\
\hline None & 1.00 & & 1.00 & & 1.00 & & 1.00 & \\
\hline Little & 1.98 & 1.08 to 3.59 & 1.98 & 1.09 to 3.63 & 1.70 & 0.92 to 3.12 & 1.66 & 0.90 to 3.05 \\
\hline Some & 2.34 & 1.10 to 4.99 & 2.35 & 1.10 to 5.01 & 1.56 & 0.73 to 3.34 & 1.55 & 0.72 to 3.31 \\
\hline A lot & 1.83 & 0.71 to 4.70 & 1.87 & 0.72 to 4.87 & 3.56 & 1.31 to 9.67 & 3.33 & 1.21 to 9.17 \\
\hline
\end{tabular}

$\star$ OR adjusted for sex, deprivation score, and total energy.

tOR further adjusted for respiratory symptoms.

Table 4 Lung function with exposure to environmental tobacco smoke measured from a combination of questionnaire and serum cotinine

\begin{tabular}{|c|c|c|c|c|c|c|}
\hline \multirow{2}{*}{$\begin{array}{l}\text { Self reported environmental tobacco } \\
\text { smoke and serum cotinine }\end{array}$} & \multicolumn{2}{|l|}{ Residual } & \multicolumn{4}{|c|}{ Case-control } \\
\hline & Mean & $95 \% C I$ & $O R^{*}$ & $95 \% C I$ & ORt & $95 \% C I$ \\
\hline \multicolumn{7}{|l|}{$\mathrm{FEV}_{1}:$} \\
\hline Low exposure $\ddagger$ & 0.158 & 2.238 to 0.293 & 1.00 & & 1.00 & \\
\hline Middle exposure $\neq$ & -0.018 & -0.859 to 0.050 & 2.88 & 1.42 to 5.84 & 2.91 & 1.43 to 5.91 \\
\hline High exposure $\ddagger$ & -0.032 & -0.126 to 0.062 & 3.12 & 1.39 to 6.99 & 3.15 & 1.40 to 7.07 \\
\hline \multicolumn{7}{|l|}{ FVC: } \\
\hline Low exposure $\ddagger$ & 0.196 & 0.031 to 0.360 & 1.00 & & 1.00 & \\
\hline Middle exposure & -0.005 & -0.093 to 0.082 & 2.08 & 1.02 to 4.21 & 2.01 & 0.99 to 4.09 \\
\hline High exposure $\neq$ & -0.070 & -0.187 to 0.047 & 2.56 & 1.15 to 5.72 & 2.49 & 1.11 to 5.58 \\
\hline
\end{tabular}

$\star$ OR adjusted for sex, deprivation score, and total energy intake.

tOR further adjusted for respiratory symptoms.

¥The 1st, 2nd and 3rd tertile values for cotinine concentrations ( $\mathrm{ng} / \mathrm{ml}$ ) were $0,0.01-1.02$ and 1.03-17.49; for exposure hours a day they were $<1,1-2$ and $>2$; and for total environmental tobacco smoke scores they were 3-4, 5-6 and 7-12. They were scored at 1 , 2 , and 3 respectively. Those with scores $3-4$ were defined as low exposure to environmental tobacco smoke $(\mathrm{n}=48)$, scores $5-7$ as middle exposure $(n=160)$, and scores $8-9$ as high exposure $(n=70)$. 
in this study four degrees of exposure to ETS were used to estimate the effect, $(b)$ our subjects were more homogeneous than those in other studies and there was probably a healthy worker effect, (c) the subjects may be more sensitive to ETS in reduction of lung function as the Scottish people have lower estimated mean vitamin $\mathrm{C}$ intake than the other populations, ${ }^{34}$ and vitamin $\mathrm{C}$ could protect the lungs, ${ }^{19} 30$ and $(d)$ more indoor ETS could be expected because in Britain most people spend most of their time inside buildings, ${ }^{28}$ housing conditions are more equivalent to France and are without the increased ventilation in America. ${ }^{20}$ We also found that compared with exposure at home and at other places, the relation between ETS at work and lung function was more significant and greater. An explanation for the greater effect of exposure at the workplace is that the subjects would be exposed for about 7 hours, whereas at other places the actual contact and exposure to cigarette smoke was shorter. ${ }^{12}$

Our study has shown a significant inverse association between exposure to passive smoking and pulmonary function in working adults, and that such an association could be dose dependent. This suggests that ETS may lead to a reduction in pulmonary function in adults. Passive smoking has been a public concern for a while, because it is a major indoor pollutant to which a substantial segment of the population is exposed. ${ }^{28}{ }^{35}$ Our findings suggest that, as well as its effects on the smoker, smoking at work may contribute to deterioration of lung function in non-smoking workmates, further evidence for its control.

This work was funded by the Scottish Office and British Heart Foundation.

1 United States Department of Health and Human Services. The health consequences of smoking: chronic obstructive lung disease. Washington, DC: USGPO, DHHS (PHS), 1984 (DHHS (PHS) 84-50205.)

2 Jaakkola MS, Ernst P, Jaakkola JJK, et al. Effect of cigarette smoking on evolution of ventilatory lung function in young adults: an 8-year longitudinal study. Thorax 1991;46:90713.

3 Tredaniel J, Boffetta P, Saracci R, et al. Exposure to environmental tobacco smoke and risk of lung cancer: the
epidemiological evidence [review]. Eur Respir f 1994;7: 1877-88.

$4 \mathrm{He}$ J, Vupputuri S, Allen $\mathrm{K}$, et al. Passive smoking and the risk of coronary heart disease: a meta-analysis of epidemiological studies. N Engl f Med 1999;340:920-6.

5 White JR, Froeb HF. Small-airways dysfunction in nonsmokers chronically exposed to tobacco smoke. $N$ Engl $f$ smokers chronically

6 Kauffmann F, Tessier JF, Oriol P. Adult passive smoking in the home environment: a risk factor for chronic airflow the home environment: a risk factor for ch
limitation. Am $\mathcal{F}$ Epidemiol 1983;117:269-80.

7 Brunekreef B, Fischer P, Remijn B, et al. Indoor air pollution and its effect on pulmonary function of adult non-smoking women. III: Passive smoking and pulmonary function. Int F Epidemiol 1985;14:227-30.

8 Svendsen KH, Kuller LH, Martin MJ, et al. Effects of passive smoking in the multiple risk factor intervention trial. Am f Epidemiol 1987;126:783-95.
9 Kalandidi A, Trichopoulos D, Hatzakis A, et al. Passive smoking and chronic obstructive lung diseases. Lancet 1987;8571:1325-6.

10 Masi MA, Hanley JA, Ernst P, et al. Environmental exposure to tobacco smoke and lung function in young adults. $\mathrm{Am}$ Rev Respir Dis 1988;138:296-9.

11 Hole DJ, Gillis CR, Chopra C, et al. Passive smoking and cardiorespiratory health in a general population in the west of Scotland. BMF 1989;299:423-7.

12 Masjedi MR, Kazemi H, Jonson DC. Effects of passive smoking on the pulmonary function of adults. Thorax 1990;45:27-31.

$13 \mathrm{Xu} \mathrm{XP}, \mathrm{Li}$ B. Exposure-response relationship between passive smoking and adult pulmonary function. $A m \mathcal{F}$ Respir Crit Care Med 1995;151:41-6.

14 Carey IM, Cook DG, Strachan DP. The effects of environmental tobacco smoke exposure on lung function in a longitudinal study of British adults. Epidemiology 1999;10: 319-26.

15 Schilling RSF, Letai AD, Hui SL, et al. Lung function, respiratory diseases, and smoking in families. Am $\mathcal{F}$ Epidemiol 1977; 106:274-83.

16 Comstock GW, Meyer MB, Helsing KJ, et al. Respiratory effects of household exposures to tobacco smoke and gas cooking. Am Rev Respir Dis 1981;124:143-8.

17 Jones JR, Higgins ITT, Higgins MW, et al. Effects of cooking fuels on lung function in non-smoking women. Arch Environ Health 1983;38:219-22.

18 Lebowits MD. Influence of passive smoking on pulmonary function: a survey. Prev Med 1984;13:645-55.

19 Kentner M, Triebig G, Weltle D. The influence of passive smoking on pulmonary function: a study of 1352 office workers. Prev Med 1984;13:656-69.

20 Kauffmann F, Dockery DW, Speizer FE, et al. Respiratory symptoms and lung function in relation to passive smoking: a comparative study of American and French women. Int $\mathcal{F}$ Epidemiol 1989;18:334-44.

21 Jaakkola MS, Jaakkola JJK, Becklake MR, et al. Passive smoking and evolution of lung function in young adults. an 8 year longitudinal study. F Clin Epidemiol 1995 48:317-27.

22 Dodge R. The effects of indoor pollution on Arizona children. Arch Environ Health 1982;37:151-5.

23 Tager IB, Segal MR, Munoz A, et al. The effect of maternal cigarette smoking on the pulmonary function of children and adolescents. Analyses of data from two populations. Am Rev Respir Dis 1987;136:1366-70.

24 Lebowitz MD, Holberg CJ. Effects of parental smoking and other risk factors on the development of pulmonary function in children and adolescents. Analysis of two longitudinal population studies. Am f Epidemiol 1988;128:58997.

25 Tunstall-Pedoe H, Woodward M, Tavendale R, et al. Comparison of the prediction by 27 different factors of coronary heart disease and death in men and women of the Scottish heart health study: cohort study. BMF 1997;315:722-9.

26 Tunstall-Pedoe H, Brown CA, Woodward M, et al. Passive smoking by self report and serum cotinine and the prevalence of respiratory and coronary heart disease in the Scottish heart health study. F Epidemiol Community Health 1995;49:139-43.

27 Carstairs V, Morris R. Deprivation and health in Scotland. Aberdeen: Aberdeen University Press, 1991.

28 Coggon D. Air pollution in homes. BMf 1996;312:1316

29 Schwarts J, Weiss ST. Relationship between dietary vitamin $\mathrm{C}$ intake and pulmonary function in the first national health and nutrition examination survey (NHANES I). $A m$ f Clin Nutr 1994;59:110-4.

30 Ness AR, Khaw KT, Bingham S, et al. Vitamin C status and respiratory function. Eur F Clin Nutr 1996;50:573-9.

31 Benowitz NL. Cotinine as a biomarker of environmental tobacco smoke exposure. Epidemiol Rev 1996;18:188-204.

32 United States Environmental Protection Agency. Respiratory health effects of passive smoking: lung cancer and other disorders. Washington, DC: Office of Health and Environmental Assessment, Office of Research and Development, 1992. (EPA/600/6-90/006F.)

33 Stober W. Lung dynamics and uptake of smoke constituents by non-smokers: a surevey. Prev Med 1984;13:589-601.

34 Gregory J, Foster $\mathrm{K}$, Tyler $\mathrm{H}$, et al. The dietary and nutritional survey of British adults. London: HMSO, Office of Population Censuses and Surveys (Social Survey Division), 1990.

35 Spengler JD, Sexton L. Indoor air pollution: a public health perspective. Science 1983;221:9-17. 


\section{LETTERS}

\section{Methodological problems in a case-referent study based on a register of occupational asthma}

Meredith et al, ${ }^{1}$ performed a case-referent study to investigate asthma caused by isocyanates. They claimed that the results indicated that isocyanate asthma occurs at low 8 hour average exposure (around $1.5 \mathrm{ppb}$ ); for exposures above $1.125 \mathrm{ppb}$ there was about a threefold increased risk, however, this was of limited significance (odds ratio $(\mathrm{OR})=3.2$ $95 \%$ confidence interval (95\% CI) 0.96 to 10.6 $\mathrm{p}=0.06$ ). They also concluded that their study, by contrast with other studies, had a higher risk of isocyanate asthma in smokers and people with atopy

The study design is original as cases were recruited from a register of occupational asthma. A case-referent study based on a register of cases with both the disease and the exposure of interest is new. I think the design requires some discussion as it may introduce severe bias.

A typical case-referent study selects cases with a certain disease-for example, asthma-from a hospital register or in a population survey. ${ }^{2}$ The referents should be selected to give an unbiased estimate of frequency of exposure in the study base. ${ }^{3}$ The study base of a register, including cases of occupational asthma, is the population that if the case had asthma would be reported to the register. Therefore, the authors of this study matched the referents to the cases by reporting doctor and factory or production area. Then they measured or estimated the exposure level for both cases and referents and found that the average 8 hour exposure was higher among cases. This design has certain weaknesses illustrated by the following hypothetical situations:

(1) Assume that the exposure in the production area is homogenous. Then both cases and referents would have the same exposure and the conclusion would be that the risk was independent of exposure level.

(2) Assume that the reporting doctor only knows a proportion of incident cases, a reasonable assumption. If seeing the doctor is dependent on exposure level, a bias is obvious

(3) Assume that there was no increased risk at all in the workplaces at the current exposure but that there was exposure to irritants, which varied within the production area. Then cases with asthma would probably be more likely to report problems with their asthma to the occupational health physician. There would also be an association with all substances the concentration of which was correlated with the irritant.

(4) Assume that there was no causal association between the exposure and the occurrence of asthma at the current levels. As asthma is common among people with atopy, the study would certainly indicate that atopy was a risk factor in combination with the exposure.

Some of these biases could be avoided if there was some specific test that with certainty established the causal association between asthma and the exposure among the cases. Asthma caused by isocyanates can with some certainty be established by provocation, but the study by Meredith et al included no routine provocation test.

If it is presumed that all the reported cases really are caused by isocyanates, a rather improbable assumption according to the case definition, the conclusion by the authors that isocyanate asthma occurs also at very low exposures without any threshold could be made without doing any case-referent analysis. They could just simply measure the exposure of the cases and conclude that the lowest measured exposure obviously caused isocyanate asthma. It is obviously impossible to determine any other threshold.

Is there a proper design of a case-referent study based on cases identified through a register where the association between exposure and outcome is already established? If the disease is caused by short term high exposure a case cross over design seems possible. ${ }^{3} \mathrm{How}$ ever, that design requires a very accurate determination of when the disease started which rarely is possible for asthma. Another possibility is to estimate the study base from which the cases are recruited-for example, in the study by Meredith et al the number of person-years in the different production areas where the cases were detected should have been estimated. This requires that all or most incident cases from that area are known or there should at least not be any differential reporting of cases between the areas. Thus, the design of this study is interesting but includes many possibly biases of which a just a few were discussed in the paper. The conclusions that the risk of isocyanate asthma is increased at concentrations around 125 $\mathrm{ppb}$, and is more common among people with atopy and smokers are questionable.

B Jarvholm

Department of Public Health and Clinical Medicine, Umea University, SE-901 85 Umea, Sweden; bengt.jarvholm@envmed.umu.se

\section{References}

1 Meredith SK, Bugler J, Clark RL. Isocyanate exposure and occupational asthma: a case referent study. Occup Environ Med 2000:57:830-6.

2 Toren K, Jarvholm H, Hrisman J, et al. Adult onset asthma and occupational exposures. Scand I Work Environ Health 1999:25:430-5.

3 Rothman KJ, Greenland S. Modern epidemiology, 2nd ed. Philadelphia Lippincott-Raven, 1998.

\section{Authors' reply}

We are grateful to Jarvolm for his comme nts on our paper. The specified aim of our study was to quantify the relation between the level of occupational isocyanate exposure and risk of developing asthma. The usual approach to this problem is a cohort study in an exposed workforce, possibly with a nested casereferent analysis. A register based case referent study of the type described by Jarvolm would be unsuitable for this purpose because the source population would be ill defined, selection of a appropriate referents difficult, and reliable assessment of their exposure almost impossible. We used the SWORD reporting scheme, not as a register, but as a convenient means of identifying workplaces from which clusters of cases of asthma attributed to isocyanates have been reported, and in which exposure to isocyanate had been assessed by an occupational hygienist; we then investigated those sites. A few additional cases were identified during the course of the investigation and were included in the analysis. In company A, where most of our cases worked, all employees were subject to close respiratory supervision throughout their employment, including pre-employment assessment; in company B, the occurrence of the cluster of cases was recognised by the occupational health department and the workers in the relevant areas investigated. We are therefore reasonably confident that no cases were missed.

We were careful to select referents from workers who were exposed to isocyanates and were under the same level of surveillance as the cases to avoid some of the biases outlined by Jarvolm. We agree that the close matching of cases and referents probably reduced the sensitivity of the study, but we thought that it was more important to do that than to risk selection bias as described in his second hypothetical scenario. As we also acknowledged in the article, we cannot exclude the theoretical possibility that the cases of asthma were not caused by isocyanates, but by other chemicals present in the plants. Confounding is a risk in any observational study, although not necessarily a source of bias, but the other agent would have to be closely correlated with the isocyanate exposure to account for our findings.

The cases had work related asthma as diagnosed by an occupational physician. Nearly all had a history of symptoms associated with work that improved on days away from work and had had serial respiratory function tests that supported the diagnosis. Challenge tests are rarely used in the United Kingdom; very few centres undertake them, and without proper facilities are considered dangerous. However, as explained in the article, in company A people with respiratory symptoms were removed from exposure to isocyanates until they had recovered and then gradually returned to their previous work under very close supervision with serial respiratory function testing, which in practice was a form of challenge test.

The purpose of undertaking a case-referent study was not to establish that it is possible to develop isocyanate asthma at low exposures, but to examine the exposure-response relation. We do not conclude from our data that there is a threshold below which isocyanate exposure is safe. The concentration of 1.25 ppb was arbitrarily chosen because it was the median time weighted average exposure in the referent group in company A. Despite the fact that all estimated 8 hour time weighted average exposures were within the maximum exposure limits, those subjects whose estimated 8 hour time weighted average was greater than $1.25 \mathrm{ppb}$ seemed to be at increased risk of occupational asthma. However, the data were also compatible with a linear exposure-response relation in which the odds of asthma increased by 1.08 for every 0.1 
ppb. A much larger study would be needed to test these two possible exposure-response relations fully.

S Meredith

J Bugler

R Clark

MRC Clinical Trials Unit, 222 Euston Road, London NWI 2DA, UK

Correspondence to: Dr S Meredith, Department of Preventive Medicine, Vanderbilt University, Nashville, Tennessee 37232-2637, USA

sm@ctu.mrc.ac.uk

\section{Response to a case of occupational asthma due to the enzymes phytase and $\beta$-glucanase}

In their recent short report, $\mathrm{O}^{\prime}$ Connor et al describe a case of occupational asthma due to the enzymes phytase and $\beta$-glucanase. Their patient experienced asthma-like symptoms a work (wheezing and cough), had positive skin prick tests and specific IgE to both enzymes (by radioallergosorbent test), and reacted to both materials in separate inhalation challenge tests. None of 22 other employees in the same factory were reported to have experienced respiratory symptoms at work.

In a German language paper presented at the 38th Annual Meeting of the German Association of Occupational and Environmental Medicine in $1998,{ }^{2}$ we reported findings of a systematic clinical investigation of 49 research and development employees working with the enzymes phytase and xylanase. This investigation was undertaken after detecting airway sensitisation to dusts containing phytase in two analytical laboratory employees.

Forty nine employees with potential contact to the enzyme completed a questionnaire and underwent physical examination and lung function testing. Among 32 employees with findings of conjunctivitis, rhinitis, or bronchitis further immunological tests were undertaken on a voluntary basis (skin prick test, $n=17$; specific IgE by enzyme allergosorbent test (EAST), n=31). Also, nasal provocation challenge tests were performed in 13 employees, including all 11 with a positive skin prick test to phytase. Nine of these employees had a positive specific IgE test to phytase as well. All 11 had a positive nasal challenge response to phytase. The positive response rate was $62.5 \%$ among eight employ ees considered to have the highest potentia exposure. Based on this investigation, it was concluded that phytase has a high sensitising potency. Our assessment of this is consistent with that of O'Connor et al and Doekes et al..$^{13}$

After implementation of extensive contro measures to prevent enzyme exposure in this research and development facility, all employees now report being free of work related res piratory symptoms. This favourable experience agrees with the hypothesis that enzyme related asthma can be avoided by implementing best practice procedures for health surveillance and environmental control when working with enzymes. ${ }^{4}$

A Zober K Strassburger Occupational Medicine and Health Protection Department, BASF Aktiengesellschaft, D-67056 Ludwigshafen, Germany

X Baur

University of Hamburg 22083 Hamburg, Germany

Correspondence to: Professor A Zober andreas.zober@basf-ag.de

References

1 O'Connor TM, Bourke JK, Jones $M$, et al. Report of occupational asthma due to phytase and $\beta$-glucanase. Occup Environ Med 2001;58:417-19.

2 Strassburger K, Bossert J, Baur X, et al. Sensibilisierung durch die Enzyme Phytase and Xylanase. In: Hallier E, Bünger J, eds. Dokumentationsband über die 38. Dokumentationsband über die 38. Arbeitsmedizin und Umweltmedizin. Lübeck: 1998:525-7. (ISBN: 3-7900-0302-6)

3 Doekes G, Kamminga N, Helwegen L, et al Occupational lgE sensitisation to phytase, a phosphatase derived from Aspergillus niger Occup Environ Med 1999;56:454-9.

4 Nicholson PJ, Newman Taylor AJ, et al. Current best practice for the health surveillance of enzyme workers in the soap and detergent industry. Occup Med 2001;51:81-92.

\section{Nasal, eye, and skin irritation in dockyard painters}

Chen et al report irritant symptoms experienced by dockyard painters in both Scotland and China. ${ }^{1}$ In 1985, I reported ${ }^{2}$ on painters involved in submarine refit work in one of Her Majesty's dockyards in England. I too found a high prevalence of symptoms of irritation. However, and possibly of more concern, the painters in my study also reported narcotic symptoms. In 106 painters, 74 (70\%) reported episodes of light headedness. Some 28 (26\%) reported that, on occasion, this had led them to stop painting and seek fresh air. A solvent taste in the mouth was reported by 75 (71\%). Some reported that their partners complained of a solvent smell to their breath persisting into the evening after a day shift.

The full face air fed masks then meant to be in use as respiratory protective equipment were considered to be bulky, uncomfortable, and to restrict vision. They were almost universally disliked; instead, some painters preferred to wear half face masks and tolerate eye irritation from the paint vapours, and for "touch ups" sometimes used no respiratory protective equipment.

The messages were that painters, and perhaps their supervisors as well, needed to be reminded of the importance of narcotic symptoms; if a less potentially toxic paint system could not be found, additional consideration needed to be paid to ventilation and a search made for a more comfortable air fed mask.
My study predated both Control of Substances Hazardous to Health Regulations $(\mathrm{COSHH})^{3}$ and Personal Protective Equipment at Work Regulations (PPE) ${ }^{4}$ : one might have hoped that their principles and implementation would have led to fewer irritant symptoms than still apparently being experienced by the workers in the study of Chen et al. Finally, as well as the points in their paper, I would suggest occupational physicians with painters in their care remain vigilant for narcotic symptoms. There seems to remain scope for improved control.

Occupational Health and Safety Unit, Derriford Hospital, Plymouth PL6 8DH, UK; gerard.woodroof@phnt.swest.nhs.uk

\section{References}

1 Chen R, Semple S, Dick F, et al. Nasal, eye, and skin irritation in dockyard painters. Occup Environ Med 2000:58:542-3.

2 Woodroof G. Submarine painting: a cross-sectional epidemiological investigation into work-related symptoms and lung function. J R Nav Med Serv 1985;71:98-100. 3Control of Substances Hazardous to Health Regulations. London: Health and Safety Commission, 1988

4 Personal Protective Equipment at Work Regulations. London: Health and safety Commission, 1992

\section{CORRECTION}

Environmental tobacco smoke and lung function in employees who never smoked: the Scottish MONICA study. R Chen, H TunstallPedoe, R Tavendale. 2001;58:563-8.

In figures 1 and 2 the vertical axis in both of the lower graphs should be FVC.

\section{NOTICE}

\section{Environment and health:} regional decisions: global impact. Environment and Health Seminar. 17 April 2002. University of Leicester, UK.

The Institute for Environment and Health in Leicester, UK, are holding a l day open seminar to debate how public, special interest groups, scientific and policy concerns, and decisions made in developed countries can influence decision making and subsequent impacts on environment and health in developing countries.

Cost: $£ 100$ (includes refreshments and lunch).

For more information or a registration form and programme, please contact Mrs Gail Marvin, Tel: + 44 (0)116 2231611, email: gm59@le.ac.uk or visit our website: http:// www.le.ac.uk/ieh/update/update 